\title{
„NOSTALGIA TO TĘSKNOTA ZA RAJEM”. PROBLEM NOSTALGII W POWIEŚCI ZBIERACZ RAJU JEWGIENIJA CZYŻOWA
}

Nostalgia coraz częściej pojawia się we współczesnej rosyjskiej przestrzeni medialnej i kulturowej ${ }^{1}$. Urzeczywistnia się ona w różnych formach, takich jak stylizowane na minione epoki reklamy, działalność retro-grup w serwisach społecznościowych, realizacje tekstowe i wizualne. Estetyka nostalgii, jak twierdzi Swietłana Boym, rozprzestrzeniła się szczególnie pod koniec XX wieku wraz z umocnieniem się awangardowej utopii futurystycznej (Boym 15). Dmitrij Gorin, pisząc o pułapce utopii, zauważa, że „«Świetlana przyszłość» (jak i następująca po niej «świetlana przeszłość») jest zdecydowanie oderwana od aktualnej rzeczywistości i jawi się nie jako jeden z modusów czasu historycznego, ale jako przejaw swoistej «równoległej» rzeczywistości”2 (Gorin 109). Logiczną kontynuacją tego procesu stała się „retrotopia XXI wieku, ujawniająca się «w obrazach utraconej/ skradzionej/porzuconej i złudnej przeszłości»” (Bauman 20).

Za wydarzenie, które spowodowało eksplozję nostalgicznych nastrojów w Rosji lat 1990., powszechnie uważany jest rozpad Związku Radzieckiego. W rezultacie w krajach bloku wschodnioeuropejskiego pojawiły się odmiany nostalgii - Ostalgia i Jugonostalgia, a w krajach skandynawskich - Nordic nostalgia (Klivis 65). Za ilustrację tego zjawiska może posłużyć wydana w Polsce w 2002 r. antologia Nostalgia. Eseje o tęsknocie za komunizmem,

Dr hab. ElżBieta Tyszkowska-KasprzaK, prof. UWr - Uniwersytet Wrocławski, Wydział Filologiczny, Instytut Filologii Słowiańskiej; adres do korespondencji: ul. Pocztowa 9, 53-313 Wrocław; e-mail: elzbieta.tyszkowska-kasprzak@uwr.edu.pl; ORCID: https://orcid.org/00000001- 8297-0630

${ }^{1}$ Przegląd badań nad nostalgią w kulturze przytaczam za artykułem autorstwa mojego i Natalii Siemionowej (Semenova i Tyshkovska-Kaspshak 7-10).

${ }^{2}$ Tu i w cytatach, gdzie nie jest podane nazwisko tłumacza, przekład mój - E.T.-K. 
zawierająca teksty przedstawicieli różnych narodów Europy Środkowo-Wschodniej (Nostalgia. Eseje). Wyróżnienie odmian nostalgii zgodnie z kryterium geograficznym stanowi potwierdzenie myśli Boym o dwóch

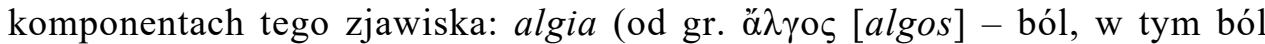
moralny) to tęsknota, która jest jednakowa dla wszystkich, i nostos (gr. vó $\sigma$ $\tau o \varsigma[$ nostos] - powrót do domu) - nawiązanie do pojęcia domu, dzielącego ludzi na swoich i obcych (Boym 120). Chociaż tęsknota jest dla wszystkich jednakowa, to „nie przeszkadza nam opowiadać zupełnie różnych historii o przynależności i odrębności” (Boym 103). Związek nostalgii z problemem tożsamości akcentują też inni autorzy (Sukhanov 17-22; Klivis 64).

Większość badaczy nostalgii uznaje czas i przestrzeń za jej kluczowe kategorie. Czasowy aspekt tego zjawiska jest często łączony z dyskursem pamięci i traumy, szczególnie, jak twierdzą Sergey Toymentsev (Toymentsev 296-319) i Aleksandr Etkind (Etkind 209-220), w przypadku nostalgii postradzieckiej. Liudmila Mazur charakteryzuje ją jako „kolektywną pamięć historyczną, której właściwe jest intensywne działanie emocjonalne i ideologiczna podstawa" (Mazur 214). Laurajane Smith i Gary Campbell akcentują emocjonalne nasycenie procesu wspominania i wydzielają reakcyjną oraz progresywną odmianę nostalgii. Ta ostatnia nie idealizuje przeszłości, a uznaje jej złożoność (Smith 613-614, 623).

W zależności od typu czasu - historycznego bądź mitologicznego - Wiaczesław Suchanow wyróżnia dwa typy subiektów nostalgizujących po czasach radzieckich: pierwszy ma osobiste egzystencjalne doświadczenie przeżywania, a drugi odbiera tamte czasy za pośrednictwem różnego rodzaju narracji przeszłości, czyli poprzez mit (Sukhanov 21-22). Takie samo podejście stosuje David Berliner, pisząc o endonostalgii, czyli tęsknocie za przeszłością, którą przeżyło się osobiście, i egzonostalgii, powstającej na poziomie emocji, kiedy podmiot znajdował się poza obiektem nostalgii (Berliner, Multiple nostalgias 781-782; Are Anthropologist Nostalgist 21-22).

Nostalgia może być także atemporalna. Serguei Oushakine podkreśla pragmatyczną stronę nostalgii, podkreślając, że stare, znane formy mogą być wykorzystane w nowym historycznym kontekście i niekoniecznie powinny one odpowiadać pierwotnemu znaczeniu (Oushakine 453). Opinia ta koreluje z myślą Aleksandra Etkinda, określającego pamięć postsowiecką jako „kombinację różnych symboli, epok i opinii, które przeżywane są jednocześnie" (Etkind 213). Ekaterina Kalinina stosuje inną klasyfikację i wyróżnia nostalgię modernistyczną i postmodernistyczną. Pierwsza opiera się na pojęciu moderny, wierze w postęp, możliwość kontrolowania przyszłości i prezentuje 
swój opór wobec czasu historycznego, jego linearności i dynamiki. Drugiemu typowi właściwe jest poczucie zaniku dystansu historycznego i według badaczki stanowi on raczej stylizację niż autentyczne przeżywanie (Kalinina 53-55).

Przestrzenny aspekt nostalgii oddaje, chociaż nie wyczerpuje, metafora „utraconego domu”. Stosunkowo nowe zainteresowanie pamięcią lokalną, refleksja o związku człowieka z jego środowiskiem życia, badanie praktyk socjokulturowych ukierunkowanych na budowanie tożsamości i przynależności do konkretnego miejsca - wszystko to pozwala traktować nostalgię jako zjawisko związane z kategorią geograficzną (Colin 495-496). W tym kluczu rozpatruje nostalgię Clément Colin, wspominając jednocześnie o szczególnej jej formie - emocjach, których doznają mieszkańcy miast pod wpływem zmian urbanistycznych (procesów rekonstrukcji, wyburzeń, budowy nowych obiektów w znanych im miejscach) (Colin 497).

Już w tym krótkim przeglądzie opinii o nostalgii można zauważyć płynność jej definicji i różnorodność aspektów z nią związanych. Zaproponowane przez badaczy typy nostalgii, pozostające najczęściej we wzajemnej opozycji, wchodzą w różnorakie z sobą relacje, tworząc hybrydy. W tej rozmaitości teorii można jednak zauważyć stałe, oprócz tęsknoty, komponenty: pamięć, czas i przestrzeń oraz ich przeżywanie.

Nostalgia, czas, przeszłość i jej wpływ na teraźniejszość, pamięć i jej zanik - to węzłowe problemy powieści Jewgienija Czyżowa Zbieracz raju ${ }^{3}$ (Собиратель рая, 2019). Czyżow, moskiewski prozaik średniego pokolenia, znany z utworów Ciemna przeszłość człowieka przyszłości (Темное прошлое человека будущего, 2000), Postać bez roli (Персонаж без роли, 2008), Ttumaczenie z ,rybki” (Перевод с подстрочника, 2013), największy do tej pory sukces odniósł dzięki powieści Zbieracz raju, która w 2020 r. przyniosła mu prestiżową nagrodę literacką „Jasna Polana”.

Pisarz $\mathrm{w}$ jednym $\mathrm{z}$ wywiadów przyznał, że czas jest nadrzędnym zagadnieniem jego prozy:

U francuskiego pisarza Henry'ego de Montherlanta przeczytałem zdanie, że od określonego wieku człowieka interesuje poważnie jedynie problem czasu. To oczywiście teza przesadzona, ale jednak czas to po prostu nić, na którą nawlekają się momenty życia i która przechodzi przez serce. Dla mnie temat ten jest kluczowy od pierwszej powieści; można powiedzieć, że to moja idée fix. (Chizhov, Pisateli)

${ }^{3}$ Do tej pory żaden z utworów Jewgienija Czyżowa nie został przełożony na język polski. Ten i kolejne tytuły podaję we własnym tłumaczeniu - E.T.-K. 
Akcja powieści Zbieracz raju rozgrywa się w latach 90. ubiegłego wieku - „parszywych 90.” (лихие 90-e), które przyniosły Rosjanom psychologiczną traumę, spowodowaną rozpadem Związku Radzieckiego, zabrały poczucie pewności, zakorzenienia, wiarę w ideały i wartości poprzedniej epoki. Nałożył się na to szok związany z przemianami ekonomicznymi, prowadzącymi do ogromnego rozwarstwienia społeczeństwa. Pozbawieni w ten sposób materialnej i etycznej bazy Rosjanie poszukiwali oparcia w systemie norm, który niedawno odrzucili (Brushlinskiy 241). Temu etapowi dziejowemu Czyżow poświęcił też wcześniejszą powieść - Ciemna przeszłość człowieka przyszłości, nazywaną przez niektórych krytyków najlepszą książką o latach 90. (Chizhov, Pro menya).

Kondycja Rosjan lat 90. była przedmiotem literackiej refleksji w wielu utworach końca XX - początku XXI wieku. W takich tekstach, jak na przykład Życie owadów (Жизнь насекомых, 1993), Generation П (1999) Wiktora Pielewina, Uczta (Пup, 2000) Władimira Sorokina, Melina oświeconych (Притон просветленных, 2001) Anastasii Gostiewej, Popiót (Зола, 2008) Andrieja Iwanowa, Życie z ирiorami (Жизнь с призраками, 2010) Andrieja Matwiejewa został zaprezentowany kryzys wartości, utrata wiary we wcześniej wyznawane idee, brak orientacji w nowej rzeczywistości, co skutkowało rozpadem osobowości, utratą tożsamości, poczuciem pustki duchowej, krachem relacji międzyludzkich (Govorukhina, Kaminskiy i Sukhanov 284-302).

Marina Aleksandrowa w recenzji nazwała utwór Zbieracz raju „powieścią-postkatastrofą" (Aleksandrova). Przedstawia on ludzi, którzy zostali pozbawieni swojego kraju, a cała ich przyszłość pozostała w przeszłości. Czas się dla nich zatrzymał i pozostaje im zanurzenie we wspomnieniach zmaterializowanych w starych przedmiotach. W centrum fabuły pisarz ulokował dwie postaci, których najważniejszym rysem jest stosunek do czasu, przeszłości, pamięci: Kiriłła zwanego Królem, stałego bywalca moskiewskich pchlich targów, cenionego kolekcjonera, znawcę stylów minionych epok, i jego chorą na Alzheimera matkę. Czyżow przyznaje, że kiedyś sam należał do podobnej kompanii: „To byli swego rodzaju bikiniarze lat 90., którzy, w odróżnieniu od bikiniarzy lat 50., brali za wzór nie Amerykę, a radziecką przeszłość, natomiast tak samo demonstracyjnie przeciwstawiali się swoim czasom" (Chizhov, Kak nam obustroit' ray?).

Ten zwrot ku przeszłości jest w ostatnich latach właściwy nie tylko Rosjanom. Jak zauważa Aleida Assman: „Światło teraźniejszości obecnie blednie, a wraz z tym przeżywamy jeszcze jedną anomalię zwykłej percepcji czasu, a mianowicie przywracania przeszłości na niespotykaną wcześniej 
skalę" (Assman 4). Na początku XXI wieku to przeniesienie zainteresowania z przyszłości na przeszłość zauważył Andreas Huyssen, który stwierdził, że jest to jedno z najdziwniejszych zjawisk w kulturze i polityce od lat 80 . Podczas gdy motorem kultury modernizmu była „teraźniejszość przyszłości”, to w następnych dziesięcioleciach uwaga całych społeczeństw skupiła się na „teraźniejszości przeszłości” (Huyssen 21). Te spostrzeżenia potwierdza w swoich badaniach niemiecki futurolog Werner Mittelstaedt, utrzymując, że w ostatnich dziesięcioleciach zwrot ku przeszłości spowodował, iż pojęcie postęp utraciło swój dawny blask (Mittelstaedt 12). W badaniach socjologicznych i kulturowych ostatnich dekad ma miejsce swoista „epidemia pamięci”4 - o pamięci pisze się i mówi niezmiernie często, włączając ją do wciąż nowych sfer życia.

Pamięć, a co za tym idzie - przeszłość stają się szczególnie ważne w sytuacji zagrożenia tożsamości grupy, co miało miejsce po rozpadzie Związku Radzieckiego. Amerykański historyk Allan Megill stawia tezę, że „kiedy tożsamość staje się wątpliwa, wzrasta wartość pamięci” (Megill 137). Chodzi tu niewątpliwie o pamięć zbiorową, która jest pierwotna, gdyż zawsze pamiętamy jako przedstawiciele określonej grupy - wspólnoty pamięci (Napiórkowski 19). W powieści Czyżowa takim okresem zagrożenia były lata 90., dużym jednak uproszczeniem byłoby stwierdzenie, że Zbieracz raju to utwór historyczny, zahaczający o zagadnienia polityczne. Pisarz podejmuje bowiem temat człowieka w czasie, jego relacji z przeszłością i teraźniejszością, wpływu historii na jego świadomość, nostalgii po czasach przeżytych i wyobrażonych.

Tytułowy bohater powieści Czyżowa, obsesyjnie gromadząc przedmioty minionej epoki, niejako buntuje się przeciw płynności, zmienności świata w czasie, przemijaniu. Kolekcjonerstwo Kiriłła ma szczególny charakter zbiera on rzeczy pospolite, niegdyś powszechnie używane, ocalone przypadkowo, których wartość polega na zamkniętym w nich czasie. Większość recenzentów powieści wskazuje na nostalgię po Związku Radzieckim jako na nadrzędny temat utworu (Sekretov; Chantsev). Chociaż w powieści rzeczywistość radziecka łączy się z perspektywą postradziecką, nie znajdziemy tu oceny minionych czasów ani tym bardziej ich idealizacji i w związku z tym nie można utworu nazwać nostalgicznym.

\footnotetext{
${ }^{4}$ Metafora epidemii została zastosowana przez Malcolma Gladwella (13). Marcin Napiórkowski wymienia też inne określenia ogromnego zainteresowania zagadnieniem pamięci: „czas pamięci”, „gorączka pamięci”, „,boom pamięciowy”, „szaleństwo pamięci”, „,nadmiar pamięci” (16).
} 
W literaturze ostatniej dekady XX wieku i pierwszych dziesięcioleci wieku XXI czasy ZSRR były przedstawiane w tonie ironicznym czy satyrycznym, np. Tam $i$ z powrotem (Туда и обратно, 1993) Wiaczesława Pjecucha, Rozmyślania poza okolica historii (Размышления за околицей истории, 2008) Jekatieriny Klimakowej, Ludzie w gołym (Люди в голом, 2009) Andrieja Astwacaturowa. Na przełomie wieków brak koniecznego dystansu czasowego i pozycji odrębnej w stosunku do epoki radzieckiej były przyczyną nieobecności wśród autorów postaw nostalgizujących (Govorukhina, Kaminskiy i Sukhanov 293). Pod koniec pierwszego dziesięciolecia XXI wieku pisarze coraz częściej sięgają do historii minionej epoki, bohaterowie utworów nie potrafią się rozstać z przeszłością, starają się zrozumieć specyfikę radzieckiej utopii i swoje imperialne kompleksy, np. w powieściach Stepowi bogowie (Степные боги, 2008) Andrieja Giełasimowa, Żurawie i karty (Журавли и карлики, 2008) Leonida Juzefowicza, Kamienny most (Каменный мост, 2009) Aleksandra Tieriechowa. Trudno tu odnaleźć próby obrachunku z tym okresem, ideologia komunistyczna nie jest przedmiotem tęsknoty, za to pojawia się żal za utraconym imperium $\mathrm{w}$ sensie terytorialnym i wielkomocarstwowym (Litovskaya 328-332).

Zbieracz raju nie zawiera wspomnień bohaterów o minionej epoce, w związku z tym nie ma tu poczucia braku konkretnych zjawisk radzieckiej przeszłości. Powieść traktuje o nostalgii jako zjawisku niezwykle rozpowszechnionym po upadku ZSRR, a które $\mathrm{w}$ utworze zaprezentowane zostało za pomocą metafor kolekcjonowania i choroby Alzheimera. „Interesuje mnie nostalgia jako diagnoza - pisał Czyżow - jako choroba, na którą cierpią prawie wszyscy" (Chizhov, Pisateli).

Nostalgia - jak pisze Swietłana Boym -

to uczucie utraty i odsunięcia, ale też gra $\mathrm{z}$ własną fantazją. [...] W szerszym znaczeniu nostalgia to sprzeciw wobec modernistycznego pojmowania czasu, czasu historii i postępu. Nostalgia to pragnienie likwidacji historii i przekształcenia jej w prywatną lub kolektywną mitologię, powrotu do innych czasów $[\ldots]$ odmowa podporządkowania się nieodwracalności czasu. (Boym 12,14)

Powszechność nostalgii w Rosji lat 90. zauważa i objaśnia bohater powieści - poczatkujący pisarz, Karandasz:

- Меня еще вот что удивляет: о прошлом ведь, по идее, старики должны думать, которые до будущего всё равно не дотянут, будущее - оно для молодых. Так нет же, теперь молодые ностальгируют по временам, когда их еще 
и в помине не было! [...] - Я это только тем объясняю, что всё наше будущее осталось в прошлом. И чтобы вновь открыть для себя будущее, надо сперва вернуться назад. (Chizhov, Sobiratel' raya 26)

Czyżow przedstawia problem nostalgii, odwołując się do symptomów patologicznych, czynników szkodliwych dla człowieka:

Ностальгия - это наркотик, отравивший кровь настоящего, а прошлое, которое давно умерло, давно не существует, - вампир, сосущий кровь сегодняшнего дня, нашу с тобой кровь! [...] Да, прошлое, может, и освобождает от настоящего, но взамен подчиняет себе еще сильнее! (Chizhov, Sobiratel' raya 87)

W innym miejscu wprost nazywa ją chorobą: „Ностальгия - это болезнь, исподволь подтачивающая силы, лишающая вкуса к реальности, принуждающая жить в несуществующем мире!" (Chizhov, Sobiratel' raya 26). W takim podejściu do nostalgii pisarz sięga do dawnych określeń tego zjawiska. Nostalgia była bowiem opisana po raz pierwszy w XVII wieku jako choroba spowodowana tęsknotą za przeszłością, a głównie za porzuconym krajem, i zgodnie z charakterystyką oprócz symptomów psychicznych powodowała również objawy fizyczne (Louental' 36-37). Jean Starobinski w rozważaniach o rozszerzaniu zakresu znaczeniowego terminu nostalgia podkreśla, że samo zjawisko istniało dużo wcześniej: „Ludzie odczuwali nostalgię, zanim to uczucie zyskało naukowe miano, podobnie jak sadyzm istniał przed markizem de Sade, a Ziemia obracała się przed Kopernikiem" (Starobinski 205). Szwajcarski filozof stawia też tezę, że nazwa i popularyzacja określonego stanu emocjonalnego w tekstach kultury staje się czynnikiem prowokującym zachowania czy sposób odczuwania: „Samobójstwa popełniano, zanim Goethe napisał swego Wertera, ale są ludzie, którzy nigdy nie popełniliby samobójstwa, gdyby nie przeczytali wcześniej Wertera" (Starobinski 205-206). Miało to również miejsce w przypadku nostalgii, która w XX wieku, spopularyzowana przez kulturę, stała się zjawiskiem powszechnym (Starobinski 206).

Czyżow nie naznacza swojego bohatera fizycznymi symptomami choroby. Można natomiast zauważyć u niego psychiczne i mentalne aberracje, polegające na odrzuceniu czasu, w którym przyszło mu żyć. W powieści nie znajdujemy uwag o jakichkolwiek zainteresowaniach Kiriłła związanych z bieżącą sytuacją społeczną, polityczną czy gospodarczą, nie jest obserwatorem ani tym bardziej uczestnikiem życia kulturalnego, nie pasjonuje go sport. To patologiczne wręcz odrzucenie teraźniejszości uwidacznia się też 
w braku więzi z innymi ludźmi czy instytucjami: Król nie jest nigdzie zatrudniony, jego relacje z kolegami są miałkie i niezobowiązujące, a związki z kobietami powierzchowne i krótkotrwałe. W jego charakterze oraz postępowaniu założona jest niechęć do zakorzenienia w swoich czasach, stałości, stąd jego brak zaangażowania w jakiekolwiek związki.

Postaci powieści Czyżowa zwracają uwagę na wszechobecność nostalgii: „прошлое у каждого в душе, к нему влечет неистребимая сила ностальгии - живущая в любом человеке сила сопротивления диктатуре времени" (Chizhov, Sobiratel' raya 26). Nostalgia nieuchronnie pojawia się w okresach przyspieszonego tempa życia i wstrząsów historycznych, stając się mechanizmem obronnym (Boym 13). Wspomnienie i tęsknota za ,jasną stroną przeszłości” były powszechne w Rosji lat 90. Pisano nawet o „epidemii nostalgii", na co znaczący wpływ miało upowszechnianie w kulturze i mediach pozytywnych obrazów życia w Związku Radzieckim (Ivanova 15). Jak zauważa Kiriłł: „У нас вся страна по СССР ностальгирует” (Chizhov, Sobiratel' raya 26$)$.

Nostalgia Kiriłła nie była tylko tęsknotą za znanymi mu czasami, a pragnieniem przeniesienia się do innych epok nieznanych mu z doświadczenia, czyli - zgodnie z typologią Davida Berlinera - w osobie bohatera została zaprezentowana zarówno endonostalgia, jak i egzonostalgia (Berliner, Multiple nostalgias 781-782). Ta ostatnia bodaj najwyraźniej została zobrazowana w scenie domówki u Króla, podczas której wszyscy goście weszli w klimat lat dwudziestych XX wieku, a to dzięki staraniom samego gospodarza i stylizacjom z udziałem jego strojów i rekwizytów. Autor powieści przytoczył tu cały katalog nazw elementów odzieży, z których wiele wyszło już z obiegu, np. frencz, gamasze, spodnie galife, melonik, cylinder, krawat ascot, boa ze strusich piór, kapelusz z woalką, mufka, narzutka z szynszyli.

Starania Kiriłła, by przenieść gości do innych czasów, nie ograniczały się do rozdania ubrań:

Король объяснял каждому, как обращаться с доставшейся ему вещью: как крепить вуаль, как завязывать шейный платок, как носить боа или цилиндр откуда-то он всё это досконально знал. Потом в белых перчатках и белой нейлоновой рубашке с завернутыми до локтя рукавами Король самолично смешивал для гостей коктейли [...]. Здесь он тоже был асом: знал рецепты нью-йоркских коктейлей двадцатых годов и берлинских тридцатых, любимые напитки свингующего Лондона и декадентского Парижа. (Chizhov, Sobiratel' raya 33) 
Pisarz ukazuje swoich bohaterów jako ludzi żyjących jak gdyby w dwóch światach: teraźniejszości i przeszłości, które w nostalgicznym doświadczeniu są rozdzielone i jednocześnie połączone, jak to ujmuje filozof i politolog Andriej Olejnikow: „W najbardziej ostrej formie nostalgia przejawia się w takim odczuwaniu rzeczywistości, w którym przeszłość i teraźniejszość dzięki ich konfliktowi, występują łącznie i są nierozdzielne" (Oleynikov). Natalia Iwanowa za tytuł swojej książki na temat nostalgii po radzieckiej przeszłości obrała neologizm Ностальящеe - złożenie składające się z dwóch słów: ностальгия (nostalgia) і настоящее (teraźniejsze), czym akcentuje nierozłączność świadomości w czasach postradzieckich z nostalgią po epoce socjalizmu (Ivanova). O niemożności wyzwolenia się z przeszłości mówi motto utworu Czyżowa, zaczerpnięte z Wielkiego Gatsby'ego Francisa Scotta Fitzgeralda: „Tak oto dążymy naprzód, kierując łodzie pod prąd, który nieustannie znosi nas w przeszłość"5 (Fitzgerald 238). Drugie motto, fragment Obrony dzieciństwa Martina Walsera, przynosi myśl o bezsensowności działań, które przeczą naturalnemu porządkowi rzeczy: „Nie ma nic śmieszniejszego niż starać się być oryginalnym w obliczu śmierci" ${ }^{\prime 6}$ (Chizhov, Sobiratel' raya 5).

Obsesyjne wspominanie czasów minionych i pragnienie powrotu do nich jest udziałem nie tylko Kiriłła, ale też jego „świty” - otaczających go młodych ludzi, podziwiających jego kunszt kolekcjonerski. Bocman, Wika, Lera, Karandasz i inni znajomi stale rozmawiają o Królu, wyjawiają jego filozofię, stając się jednocześnie niedoskonałymi sobowtórami swojego Mistrza. Pisarz Karandasz na przykład zwierza się z prześladującej go myśli:

- У меня самого, как, наверное, и у каждого, бывают дни, когда, кажется, всё бы отдал, чтобы хоть на день куда-нибудь назад улизнуть. Лучший из дней в настоящем обменял бы на худший в минувшем и ни секунды б не пожалел. В такие дни у меня даже что-то вроде надежды возникает, что где-то и, может, совсем даже рядом должна быть щель, сквозь которую можно в прошлое проскользнуть. Не может ведь быть, чтобы это чертово время было совершенно сплошным и непроницаемым, без единой трещины! (Chizhov, Sobiratel' raya 26 )

\footnotetext{
${ }^{5} \mathrm{~W}$ powieści motto podane jest w języku rosyjskim bez przytoczenia oryginału. „Так мы и пытаемся плыть вперед, борясь с течением, а оно всё сносит и сносит наши суденышки обратно в прошлое".

${ }^{6} \mathrm{~W}$ powieści motto przytoczone jest $\mathrm{w}$ niemieckim oryginale $\mathrm{z}$ tłumaczeniem na język rosyjski w przypisie. Przekład na język polski mój - E.T.-K. „Dem Tod gegenüber originell sein zu wollen - lächerlicher konnte nichts sein”. „Нет ничего смешнее, чем пытаться быть оригинальным перед лицом смерти".
} 
Takie idealizowanie przeszłości, charakterystyczne dla nostalgii, może być niebezpieczne, ponieważ realność jest tu mylona $\mathrm{z}$ wyobrażeniem. Długo obiecywana świetlana przyszłość nie nastąpiła, dlatego bohaterowie utworu szukają ukojenia w szczęśliwej, aczkolwiek wyimaginowanej, przeszłości. Chociaż uczucie żalu z powodu utraty swojego miejsca i niemożliwości odwrócenia biegu czasu leży w centrum odczuwania świata w modernizmie, to pisarz daje szczególną ocenę tego zjawiska, wiążąc je z mentalnością Rosjan, ich melancholijną naturą i brakiem konsekwencji. Jedna $\mathrm{z}$ bohaterek odtwarza opinię swojego męża Amerykanina o nostalgii po czasach socjalistycznych:

Колин надо мной смеется, говорит, что это моя ностальгия - особый вид сентиментальности, свойственный одним русским, точнее даже, одним бывшим советским. Все нормальные люди живут, где им удобнее, и с удовольствием пользуются преимуществами тех мест, где устроились, а не изводят себя и других, тоскуя по стране, которой больше нет. А когда она была, они только и думали, как бы им из нее сбежать. (Chizhov, Sobiratel' raya 87)

Tę antynomię w podejściu do czasów radzieckich zauważa też rosyjski pisarz i krytyk literacki Dmitrij Bykow:

Отечество привыкло к неудачам и не привыкло, чтоб наоборот, но мы ведь и по ним охотно плачем. Мы очень ностальгический народ. Посмотрим, плечи старые ссутулив, подобный трехрублевой колбасе застойный Кабачок «13 стульев» - и плачем, а тогда плевались все! Где так умеют вещь одну и ту же то оплевать, то в перлы произвесть? То ль наша жизнь становится все хуже, то ль мы себе не нравимся как есть - но жизнь без ностальгического флера всегда напоминает нам чуму. (Bykov)

Przeszłość, w której Kiriłł starał się schronić, stopniowo staje się dla niego pułapką. Nie utożsamiając się ze swoimi czasami, ukrywając za elementami odzieży z minionych epok, stopniowo traci on osobowość. Oderwanie od czasowości, rozumiane przez jego kompanów jako najwyższa forma wolności, pozbawia bohatera poczucia własnego ,ja”, co stanowi przyczynę nawracających koszmarów sennych, w których bohater nagle okazuje się nagi. Te sny męczą też inne osoby z otoczenia głównej postaci. Sny, będące - zgodnie z teorią psychoanalizy - sygnałem podświadomości, ujawniają ukryte pragnienia, kompleksy. Sen o nagości w miejscu publicznym, powodujący zawstydzenie, zażenowanie, chęć ucieczki, może świadczyć o próbie przyjęcia nowej tożsamości. Bohaterowie niezakorzenieni w swoim 
czasie pozbawieni są samoświadomości, własnych wspomnień, oparcia w realności, a starając się zaczepić w innych czasach - stają się nieautentyczni, ich wizerunek to tylko wymysł, miraż, pustka. Przyjaciółka Kiriłła Wika wyznaje: „Будто все это у меня чужое, заемное, взятое у времени напрокат, и ему это с первого взгляда видно. Так что ничего своего, кроме тела, у меня не остается" (Chizhov, Sobiratel' raya 83). Bocman thumaczy sny Kiriłła strachem przed zdemaskowaniem: „Когда снишься себе голым среди отетых [...] - это значит страх разоблачения. [...] сколько б шмотья с блошинки он ни натащил, от самого себя ему в нем не укрыться, все равно будет себе в чем мать родила сниться!" (Chizhov, Sobiratel' raya 87).

Ucieczka do przeszłości została zademonstrowana w powieści także w obrazie matki. Cierpiąca na chorobę Alzheimera kobieta jest sobowtórem Kiriłła, chociaż „podróżuje w czasie” wbrew swojej woli. Jej dolegliwość najlepiej obrazuje życie w dwóch wymiarach czasowych, staje się metaforą nostalgii - metaforą dość przejrzystą, sugerującą brak równowagi między jednostką a otoczeniem, wskazującą na opresyjny charakter środowiska (Sontag, Choroba 67-68). Pisarz w sposób niezwykle poruszający opisuje kolejne fazy choroby, rozpad pamięci, skutkujący rozpadem świata chorego. W świadomości Mariny Lwowny wektor czasu odwraca się - czas zaczyna się cofać. Nie może sobie ona przypomnieć spraw bieżących, ale doskonale pamięta zdarzenia z młodości: „Если у здоровых людей настоящее день за днем оттесняет в забвение прошлое, то у Марины Львовны, наоборот, прошлое выталкивало настоящее, не давало ему оставить след в ее памяти, где больше не было места" (Chizhov, Sobiratel' raya 80).

Akcja utworu opiera się na poszukiwaniach zaginionej matki, jakie Kiriłł podejmuje w mroźny zimowy wieczór. Kobieta nie jest w stanie wrócić do mieszkania, które dzieli z synem, gdyż w jej świadomości aktualizuje się dom z czasów dzieciństwa i młodości, znajdujący się przy ulicy Teatru Artystycznego. Kłopot $\mathrm{z}$ odnalezieniem drogi wynika nie tylko z utraty pamięci, co symbolizuje sypiący gęsty śnieg, ale też ze zmian, jakie dokonały się w przestrzeni miasta. Informacji o tym miejscu udzielił Marinie Lwownie jedynie starszy mężczyzna, wyjaśniając, że takiej ulicy już dawno nie ma, że zmieniono jej nazwę, a o starej nikt nie pamięta:

Знаю я, куда твой проезд подевался. Один я знаю, больше никто тебе этого не расскажет. Сейчас память у людей короткая, а проезд твой давным-давно переименовали. Он уже лет десять как Камергерским называется, так что никто и не помнит теперь, что он прежде Художественного театра был. (Chizhov, Sobiratel' raya 68 ) 
Scena ta ilustruje nie tylko brak orientacji bohaterki w zmieniającym się otoczeniu, ale też zjawisko odnoszące się do nostalgii po dawnych miejscach, z czasem diametralnie zmienionych, sprawiających wrażenie obcych. Utrata znanych, utrwalonych $\mathrm{w}$ pamięci miejsc, a - w przypadku przestrzeni postradzieckiej - często także zmiana nazw może powodować zakłócenia w odczuwaniu tożsamości, zaburzać poczucie przynależności do własnej przestrzeni (Clément 497). Ten problem dotyczy w znacznej mierze mieszkańców Moskwy, gdzie pisarz umieścił powieściowe zdarzenia. Przemiany, jakie zaszły w tkance miejskiej stolicy Rosji, są na tyle znaczące, że starszym pokoleniom moskwian trudno się z nimi identyfikować. Sam pisarz przyznał, że nie akceptuje wielu zmian urbanistycznych i współczesna Moskwa jest mu obca: „Я нынешнюю Москву в целом не очень люблю. Мне не нравится, что город стал страшно дорогим, не нравится сусальное лицо, которое ему усердно рисуют. Скорее, как исключение, есть еще места, которые мне дороги" (Chizhov, Eto moy gorod).

Choroba Mariny Lwowny sprawia, że przywołuje ona wspomnienia z odległej przeszłości, zapominając o aktualnych faktach. Początkowo Kiriłła złości, że matka pamięta go jako małe dziecko, „как он сучил ножками, пускал слюни, игрался своими какашками и издавал нечленораздельные звуки" (Chizhov, Sobiratel' raya 12), ale w momencie, kiedy przestaje go poznawać, jest przerażony. Dla matki był jedyną bliską osobą, a kiedy wypadł z jej pamięci, została zupełnie sama:

Кроме него, у нее никого нет. А теперь, раз она не может его узнать, нет и его. Нож увяз в масле, Кирилл смотрел на мать, пытаясь нащупать прежнюю, помимо всех слов очевидную связь, и не находил ее. Что он должен сделать, как доказать, что он - это он? (Chizhov, Sobiratel' raya 13)

Matka pamięta syna jako coraz młodszego. W ten sposób zachodzi proces, o który Kiriłł w realności tak zabiega, wchodząc w role osób z innych epok. Kiedy w pamięci Mariny Lwowny, cofającej się do coraz wcześniejszych etapów swego życia, znika jedyny syn („У меня нет никакого сына”, Chizhov, Sobiratel' raya 106), oboje tracą punkt zaczepienia w teraźniejszości. Pisarz uśmierca swojego bohatera, gdy kończy się jego istnienie w świadomości matki. Z drugiej strony opieka nad nią była jedyną nicią wiążącą Króla ze współczesnością i kiedy ten obowiązek przejmuje jego wuj, bohatera nic już nie trzyma w jego rzeczywistości.

W wątku Mariny Lwowny wspomniany jest też inny sposób zatrzymania, utrwalenia chwili. W powieści kilkukrotnie pojawia się sytuacja oglądania 
przez Kiriłła fotografii, na których matka została uwieczniona jako młoda dziewczyna. Autor opisuje zdjęcia przez pryzmat spojrzenia Kiriłła, z dużej perspektywy czasowej. Przeglądanie albumów jest dla bohatera formą podróży w czasie:

Снял с полки альбом, принялся выбирать и утонул. Выпал из времени (...) Снимки затягивали его, сквозь прямоугольные окошки во времени мать, отец, родственники с той и другой стороны смотрели на Кирилла из своей черно-белой вечности, из семидесятых, шестидесятых и еще более давних, довоенных лет. (Chizhov, Sobiratel' raya 78)

Studiowanie zdjęć pozwala bohaterowi na przeniesienie się do czasów, które wydają mu się niebywale pociągające, doskonałe:

Он всматривался до полного погружения, до того, что начинал морщиться от заливавшего эти снимки избыточного света, ощущая глубину остановленного мгновения, его насыщенность и цельность. Прошлое обладало для Короля завершенностью, полнотой, стилем, формой - всем тем, чего лишено было настоящее, и в этой завершенности было куда достовернее и убедительнее. (Chizhov, Sobiratel' raya 10$)$

Taki proces obserwowania historii, wchodzenia w nią za pośrednictwem zdjęć, opisuje w rozważaniach o fotografii Rolland Barthes:

(...) życie osoby, które poprzedziło nieco nasze życie, utrzymuje w swoim osobnym obrębie napięcie Historii, udział w niej. Historia jest histeryczna: ustanawia się tylko wtedy, gdy ją obserwować - a po to, żeby się jej przyglądać, trzeba z niej być wykluczonym. [...] Czas, w którym moja matka żyła przede mną, to właśnie jest dla mnie Historia. (Barthes 118)

Jak twierdziła Susan Sontag: „Fotografie dają nam wyimaginowaną władzę nad - nierzeczywistą - przeszłością" (Sontag, O fotografii 16). Takie poczucie panowania nad minionymi zdarzeniami ma bohater Czyżowa wpatrujący się w zdjęcia matki.

Fotografie Mariny Lwowny uwieczniły jej wizerunek w radosnych, optymistycznych momentach: na daczy, nad Morzem Czarnym, na demonstracji pierwszomajowej, latem w Suchumi, zawsze wśród przyjaciół, zawsze $\mathrm{z}$ uśmiechem. Na jego ulubionym zdjęciu, zrobionym w czasie Festiwalu Młodzieży i Studentów w 1957 r., matka widnieje z bratem i przyszłym mężem: „Все трое смеются [...] она увлекает их вперед, радостно улыбаясь всему, что движется вокруг и навстречу" (Chizhov, Sobiratel' raya 80). 
Nastrój zdjęć oddaje atmosferę życia w tamtych czasach, pełną afirmacji teraźniejszości i wiary w przyszłość. Rok 1957 został wspomniany nieprzypadkowo, był to bowiem czas dający nadzieję na rozwój i przemiany w kraju. Po XX Zjeździe KPZR w 1956 r., na którym potępiono błędy i wypaczenia okresu stalinowskiego, nastąpił rok obfitujący w ważne wydarzenia: próby międzykontynentalnej rakiety balistycznej, wodowanie lodołamacza z napędem atomowym „Lenin”, wystrzelenie na orbitę Ziemi pierwszego sztucznego satelity, wysłanie w kosmos pierwszej żywej istoty - psa Łajki. Do tych naukowych i technologicznych sukcesów należy dołączyć właśnie VI Światowy Festiwal Młodzieży i Studentów, odbywający się w Moskwie. Był to bezprecedensowy epizod w historii radzieckiej stolicy, do tej pory odizolowanej od świata zewnętrznego. Goście festiwalu - 34 tysiące delegatów ze 131 państw świata - opanowali miasto, dając mieszkańcom możliwość kontaktu z innymi kulturami i politycznymi sympatiami. Młodzież słuchała jazzu, dyskutowała na zakazane tematy, między innymi o sztuce awangardowej. Efektem przedsięwzięcia było częściowe otwarcie ,żelaznej kurtyny", a co za tym idzie - ocieplenie atmosfery w kraju. Następstwa można było obserwować w latach 60 . w sposobie życia młodzieży, ruchu dysydenckim, śmiałych eksperymentach w literaturze, sztuce, filmie (Repin).

W powieści Czyżowa na fotografii zrobionej w czasie tego wydarzenia zostały utrwalone nie tylko postaci, ale i moment dziejowy. Kiriłł dostrzegał na twarzy matki nie tylko jej osobistą, ale też kolektywną radość, która, wyrażona w uśmiechu, trwała niezmiennie mimo upływu czasu: „Лицо менялось, тяжелело, появились морщины, потом дряблость, очки, крашеные волосы, но улыбка, казалось Кириллу, оставалась неизменной” (Chizhov, Sobiratel' raya 10).

Istotne jest, że wszystkie fotografie matki pochodziły z czasów sprzed choroby. Nasilenie objawów syndromu Alzheimera można więc odczytać jako metaforę momentu zwrotnego w dziejach całego pokolenia, którego oczekiwania i marzenia zostały zaprzepaszczone, a przyszłość obróciła się we wspomnienie młodości.

Fotografie są jednym z ważniejszych nośników pamięci rodzinnej i elementów kształtujących postpamięć (Michałowska 141). Studiowanie albumów rodzinnych daje poczucie więzi, a czasem identyfikacji z poprzednimi pokoleniami, rodzi chęć poznania ich życia i świata takimi, jakimi były w rzeczywistości (Łaguna-Raszkiewicz 162). Oglądanie fotografii przodków stanowi formę uczestniczenia w tym, co już minęło, ale nadal jest istotne w podtrzymywaniu czyjejś tożsamości, jest próbą odkrycia prawdy o przeszłości 
(Collier Jr., Collier 719). Ta „prawdziwość” fotografii, podkreślana przez badaczy, jest wykorzystywana w rozważaniach o pamięci. Jacques Le Goff sformułował tezę, że fotografia „dokonuje przewrotu w kwestii pamięci: pomnaża ją i demokratyzuje, przydaje jej precyzji i prawdziwości wcześniej nieosiągalnej w zakresie pamięci wizualnej oraz pozwala uchronić pamięć przed czasem i związaną z nim przemianą" (Le Goff 145). Wątpliwe jednak jest, czy na podstawie zdjęć można budować wiedzę o czasach minionych. Zdaniem Aleksandry Łukaszewicz Alcaraz fotografii nie należy traktować jako zwierciadła, nie pozwala ona na weryfikowanie wiedzy o istniejącym (Łukaszewicz Alcaraz 47). Jak twierdzi Marianna Michałowska, fotografie nie mogą rościć sobie prawa do statusu rzecznika rzeczywistości czy źródła poznania, ponieważ kreują i modelują świat równoległy do rzeczywistości i równoważny z nią (140).

Bohater Czyżowa kształtuje obraz przeszłości na podstawie fotografii, które jedynie wybiórczo prezentują życie w minionej epoce. Sceny utrwalone na zdjęciach są jak najbardziej autentyczne, ale Kiriłł, nie będąc świadkiem przedstawionych na nich wydarzeń, ma ograniczone możliwości samodzielnej interpretacji obrazów. Pozowane fotografie, przedstawiające radosne chwile z życia matki bohatera są tylko lepszą stroną bytu w ZSRR, można je porównać do oficjalnego przekazu medialnego tamtych czasów. Bez zastosowania właściwej ramy interpretacyjnej fotografie te tworzą złudne wyobrażenie o przeszłości i w konsekwencji rodzą nostalgię za epoką minioną.

Tęsknotę bohaterów za innymi czasami można rozpatrywać nie tylko jako zjawisko związane z krachem ideałów socjalizmu i duchową pustką lat 90. Sposób bycia Kiriłła jest motywowany nie tylko chęcią przeniesienia do innych epok, ale też frustracją wynikającą z zamknięcia człowieka w ograniczonym czasie, co uniemożliwia przeżycia wieczności. Jak to określił Nikołaj Bierdiajew, człowiek łączy w sobie wieczność i czas, ponieważ nosi w sobie „obraz Boży”, a zarazem jego życie jest ograniczone w czasie i zmienne (Augustyn 184). Zanurzenie w określonym czasie, historii jest rozumiane w powieści jako zniewolenie:

Время - вот абсолютная власть, с которой не поспоришь. (...) При любой диктатуре можно затаиться, не высовываться, жить своей жизнью, наконец, сбежать из страны - только от времени никуда не убежишь! (...) По-настоящему свободный человек должен был бы иметь такое же право на выбор своего времени. (Chizhov, Sobiratel' raya 15) 
Główna postać powieści postrzega problem nostalgii jako bardziej rozległy:

- Ностальгия не может пройти, - сказал тогда Король, - потому что она не тоска об оставленной родине. Это только так кажется, что о родине. На самом деле ностальгия - это тоска о рае. (Chizhov, Sobiratel' raya 93)

Kwestia ta pada w powieści kilkakrotnie, co świadczy o jej ważkości dla ideowej warstwy utworu. Jest ona także wyjaśnieniem tytułu dzieła. Kiriłł tłumaczy kolekcjonowanie starych przedmiotów wyobcowaniem, odseparowaniem od teraźniejszości i w związku z tym - brakiem własnego jestestwa oraz pragnieniem raju:

А когда чувствуешь, что тебя нет, то и вообще ничего, кроме тоски, не остается. Тянет и тянет, как сквозняк. И ничем эту дыру на месте себя не заткнуть. Одни мои вещички меня спасут. На каждой вещи из прошлого лежит отсвет рая! Я хотел собрать для вас рай! (Chizhov, Sobiratel' raya 108)

Należy podkreślić, że powieściowy raj nie odnosi się do żadnej religii, pisarz nie porusza tu kwestii wiary i konfesji. Raj jest dla bohatera stanem wyzwolenia i szczęśliwości, stanem, który każdy człowiek nosi na dnie duszy:

Память человека глубже его самого, и никто не может увидеть, что у нее на дне. А на дне у нее отблески того самого рая, который был до начала общей истории и будет после конца каждой отдельной. Ну, если, конечно, там не будет ада. (Chizhov, Sobiratel' raya 100)

Walerian, handlarz z pchlego targu, który ze swoich snów zna strukturę raju, przekonuje, że jest on wolny od czasu: „А о времени у них там никакого представления нет, даже не понимают, что это вообще такое часы, дни, минуты..." (Chizhov, Sobiratel' raya 92). Potrzeba istnienia poza czasem charakteryzuje głównego bohatera powieści. Myśl o skończoności egzystencji i podporządkowaniu określonemu czasowi rodzi w nim poczucie tragizmu i pragnienie przezwyciężenia swojej ograniczoności. Przyjaciel tak określa jego stosunek do czasu: „Думаешь, он только в нашем времени случайно, а в другом бы на месте был? Ничего подобного! Он из любого времени будет дезертиром в прошлое!" (Chizhov, Sobiratel' raya 87). Jego działania skupiają się na odnalezieniu sposobów przekraczania czasu i są oparte na wierze w możliwość „wypadania” ze swojej 
epoki. Jak przekonuje Marinę Lwowną przypadkowo spotkany bezdomny, jest to możliwe dzięki dziurom w czasie: „- Черные дыры, мать, они не только в пространстве - они во времени! И все в них проваливается, да никто этого не замечает" (Chizhov, Sobiratel' raya 69).

Dopiero przed śmiercią, w ostatnim śnie, Kiriłł ujrzał prawdę o życiu, jego autonomiczności, ukierunkowaniu i skończoności:

Вместе с другими пассажирами его вынесло из вагона, и на эскалаторе, несущем его мимо уплывающих вниз тусклых ламп, он понял, что ни остановить эту ползущую лестницу, ни изменить направление ее движения, ни сойти с нее уже невозможно. Там, наверху, куда она его везет, его ждет окончательное пробуждение, а с ним и разоблачение. Оно неизбежно. (Chizhov, Sobiratel' raya 111)

Postawy bohaterów powieści Czyżowa są wyrazem braku przywiązania współczesnego człowieka do swoich czasów, poczucia ograniczenia, chęci wyzwolenia się z teraźniejszości i przeżycia przeszłości. Zdarzenia przeszłe, a ściślej: byłe - to takie, które się spełniły, a tym samym - zakończyły. Ale dla człowieka przeszłość jawi się za każdym razem jako możliwość bycia, powtórzenia doświadczenia (Demin 23). Nostalgię bohaterów można odnieść do konkretnych czasów i tęsknoty za utraconą ojczyzną, ale warto spojrzeć na to zagadnienie szerzej i dostrzec w powieści myśl o pragnieniu przeżycia wieczności.

\section{BIBLIOGRAFIA}

Aleksandrova, Marina. „Yevgeniy Chizhov, «Sobiratel' raya»: lyudi bezvremen'ya i nostal'giya kak diagnoz” [Александрова, Марина. „Евгений Чижов, «Собиратель рая»: люди безвременья и ностальгия как диагно3”], regnum.ru/news/cultura/2980698.html. Dostęp 20.10.2020.

Assman, Aleyda. Raspalas' svyaz'vremeni. Vzlet i padeniye temporal'nogo rezhima moderna. Per. Boris Khlebnikov i Dmimtriy Timofeyev. Novoye literaturnoye obozreniye, 2017 [Ассман, Алейда. Распалась связь времени. Взлет и падение темпорального режима модерна. Пер. Борис Хлебников и Дмимтрий Тимофеев. Новое литературное обозрение, 2017].

Augustyn, Leszek. „Kultura transcendencji: czas egzystencjalny w ujęciu Mikołaja Bierdiajewa”. Czas w kulturze rosyjskiej, red. Andrzej Dudek, Księgarnia Akademicka, 2019, ss. 181-194.

Barthes, Roland. Światto obrazu. Uwagi o fotografii. Tłum. Jacek Trznadel. Wydawnictwo Aletheia, 2008. 
Bauman, Zygmunt. Retrotopia. Jak rządzi nami przeszłość?. Tłum. Karolina Lebek. Państwowe Wydawnictwo Naukowe, 2018.

Berliner, David. „Are Anthropologist Nostalgist?”. Anthropology and Nostalgia, red. Olivia Angé, David Berliner, Berghahn Books, 2015, ss. 17-34.

Berliner, David. „Multiple nostalgias. the fabric of heritage in Luang Prabang (Lao PDR)”. Journal of the Royal Anthropological Institute, nr 18, 2012, ss. 769-786.

Boym, Svetlana. Budushcheye nostal'gii. Novoye literaturnoye obozreniye; 2001 [Бойм, Светлана. Будущее ностальгии. Новое литературное обозрение, 2001].

Brushlinskiy, Andrey Vladimirovich. Problemy psikhologii sub' 'yekta. Institut psikhologii RAN, 1994 [Брушлинский, Андрей Владимирович. Проблемы психологии субъекта. Институт психологии РАН, 1994].

Bykov, Dmitriy. „Kakoy byl god, kakiye personazhi...”. Novaya gazeta, 25.12.2009 [Быков, Дмитрий. “Какой был год, какие персонажи...". Новая газета, 25.12.2009], novaya gazeta.ru/articles/2009/12/25/39825-kakoy-byl-god-kakie-personazhi. Dostęp 18.12. 2020.

Chantsev, Aleksandr. „Souchastiye vo vremeni” [Чанцев, Александр. „Соучастие во времени”], godliteratury.ru/projects/evgeniy-chizhov-sobiratel-raya. Dostęp 12.09.2020.

Chizhov, Yevgeniy. „Eto moy gorod”. Moskvich, 24.07.2019 [Чижов, Евгений. „Это мой город”. Москвич, 24.07.2019], moskvichmag.ru/lyudi/eto-moj-gorod-pisatel-evgenij-chizhov/. Dostęp 15.12.2020.

Chizhov, Yevgeniy. „Kak nam obustroit' ray?”. Rossiyskaya gazeta, 25.10.2020 [Чижов, Евгений. „Как нам обустроить рай?”. Российская газета, 25.10.2020], rg.ru/2020/ 10/24/evgenij-chizhov-zhizn-poslozhnee-kompiuternoj-igry.html. Dostęp 15.09.2020.

Chizhov, Yevgeniy. „Pisateli Ol'ga Slavnikova i Yevgeniy Chizhov: «Tabuirovannykh tem net. Yest' vkus» Yekaterina Pisareva” [Чижов, Евгений. „Писатели Ольга Славникова и Евгений Чижов: «Табуированных тем нет. Есть вкус» Екатерина Писарева"]. Афиша Daily, daily.afisha.ru/brain/14287-pisateli-olga-slavnikova-i-evgeniy-chizhovtabuirovannyh-tem-net-est-vkus/. Dostęp 12.10.2020.

Chizhov, Yevgeniy. „Pro menya” [Чижов, Евгений. „Про меня”], snob.ru/profile/26978. Dostęp 12.09.2019.

Chizhov, Yevgeniy. Sobiratel' raya. E-book, Izdatel'stvo AST, 2019 [Чижов, Евгений. Собиратель рая. E-book, Издательство АСТ, 2019].

Colin, Clément. „La Nostalgie comme Catégorie Géographique: une Proposition Théorique”. The Canadian Geographer / Le Géographe canadien, nr 62(4), 2018, ss. 494-504.

Collier, John Jr., i Malcolm Collier. „Zasady badań wizualnych”. Tłum. Kaja Gadowska. Fotospołeczeństwo. Antologia tekstów z socjologii wizualnej, red. Małgorzata BoguniaBorowska i Piotr Sztompka, Znak, 2012, ss. 738-760.

Demin, Il'ya. „Fenomen nostal'gii v gorizonte postmetafizicheskoy filosofii istorii». Vestnik Samarskoy gumanitarnoy akademii. Seriya «Filosofiya. Filologiya» nr 1 (11), 2012, ss. 1625 [Демин, Илья. „Феномен ностальгии в горизонте постметафизической философии истории». Вестник Самарской гуманитарной академии. Серия «Философия. Филология» №1 (11), 2012, сс. 16-25].

Etkind, Aleksandr. „Rabota gorya i utekhi melankholii”. Neprikosnovennyy zapas, nr 3, 2013, ss. 209-220 [Эткинд, Александр. „Работа горя и утехи меланхолии”. Неприкосновенный запас, № 3, 2013, сс. 209-220]. 
Fitzgerald, Francis Scott. Wielki Gatsby. Tłum. Ariadna Demkowska-Bohdziewicz. Książka i Wiedza, 1982.

Gladwell, Malcolm. Punkt przełomowy. Tłum. Grażyna Górska. Znak, 2019.

Gorin, Dmitriy. „Chuvstvo istorii v kul'ture «drugoy modernosti», ili Buratino kak zerkalo russkoy evolyutsii”. Neprikosnovennyy zapas, nr 3, 2013, ss. 107-117 [Горин, Дмитрий. „Чувство истории в культуре «другой модерности», или Буратино как зеркало русской эволюции”. Неприкосновенный запас, № 3, 2013, сс. 107-117].

Govorukhina, Yuliya Anatol'yevna, i Petr Petrovich Kaminskiy, Vyacheslav Alekseyevich Sukhanov. „Nostal'giya po sovetskomu v khudozhestvennykh diskursakh”. Nostal'giya po sovetskomu, red. Zoya Ivanovna Rezanova, Izdatel'stvo Tomskogo universiteta, 2011, ss. 279-326 [Говорухина, Юлия Анатольевна, и Петр Петрович Каминский, Вячеслав Алексеевич Суханов. „Ностальгия по советскому в художественных дискурсах”. Ностальгия по советскому, ред. Зоя Ивановна Резанова, Издательство Томского университета, 2011, сс. 279-326].

Huyssen, Andreas. „Present Pasts: Media, Politics, Amnesia”. Public Culture, Bd. 12 (1), 2000, ss. 21-38.

Ivanova, Natal'ya. Nostal'yashcheye. Sobraniye nablyudeniy. Raduga, 2002 [Иванова, Наталья. Ностальящее. Собрание наблюдений. Радуга, 2002].

Kalinina, Ekaterina. Mediated Post-Soviet Nostalgia. Södertörn University, 2014.

Klivis, Edgaras. "Nostalgia as Political Emotion: Eastern European Subjectivities in the (Post) Soviet Theatre Context". Nordic Theatre Studies, nr 21, 2009, ss. 64-73.

Le Goff, Jacques. Historia i pamięć. Tłum. Anna Gronowska i Joanna Stryjczyk. Wydawnictwa Uniwersytetu Warszawskiego, 2007.

Litovskaya, Mariya. „Sovetskaya imperiya kak tema sovremennoy literatury». Nostal'giya po sovetskomu, red. Zoya Ivanovna Rezanova, Izdatel'stvo Tomskogo universiteta, 2011, ss. 326-343 [Литовская, Мария. „Советская империя как тема современной литературы». Ностальгия по советскому, ред. Зоя Ивановна Резанова, Издательство Томского университета, 2011, сc. 326-343].

Louental', Devid. Proshloye - chuzhaya strana. Per. Aleksandr Vasil'yevich Govorunov. Izdatel'stvo «Vladimir Dal'», 2004 [Лоуэнталь, Дэвид. Прошлое - чужая страна. Пер. Александр Васильевич Говорунов. Издательство «Владимир Даль», 2004].

Łaguna-Raszkiewicz, Kamilla. „Fotografa jako źródło postpamięci”. Pedagogika Społeczna, nr 1 (59), 2016, ss. 155-164.

Łukaszewicz Alcaraz, Aleksandra. Epistemologiczna rola obrazu fotograficznego. Ku podmiotowi tak jakby i epistemologii jak gdyby. Rola fotografii w określaniu naszych tożsamości i świata wokót nas. Wydawnictwo Naukowe Scholar, 2014.

Mazur, Liudmila. "Golden Age Mythology and the Nostalgia of Catastrophes in Post-Soviet Russia". Canadian Slavonic Papers, t. 57, nr 3-4, 2015, ss. 213-238.

Megill, Allan. Istoricheskaya epistemologiya. Per. Marina Alekseyevna Kukartseva, Vladimir Yevgen'yevich Kashayev i Vladimir Sergeyevich Timonin, Kanon+, 2007 [Мегилл, Аллан. Историческая эпистемология. Пер. Марина Алексеевна Кукарцева, Владимир Евгеньевич Кашаев и Владимир Сергеевич Тимонин, Канон+, 2007].

Michałowska, Marianna. „Fotografia”. Modi memorandi. Leksykon kultury pamięci, red. Magdalena Saryusz-Wolska i Robert Traba, Wydawnictwo Naukowe Scholar, 2014, ss. 140-141.

Mittelstaedt, Werner. Das Prinzip Fortschritt. Ein neues Verständnis für Herausforderungen unserer Zeit. Peter Lang, 2008. 
Napiórkowski, Marcin. „Epidemia pamięci”. Antropologia pamięci. Zagadnienia i wybór tekstów, red. Paweł Majewski, Marcin Napiórkowski, Wydawnictwa Uniwersytetu Warszawskiego, 2018, ss. 15-37.

Nostalgia. Eseje o tęsknocie za komunizmem, red. Filip Modrzejewski i Monika Sznajderman. Wydawnictwo Czarne, 2002.

Oleynikov, Andrey. „Istoricheskiy opyt - novyy predmet teorii” [Олейников, Андрей. „Исторический опыт - новый предмет теории"], kogni.narod.ru/exper.htm. Dostęp 10.09. 2020.

Oushakine, Serguei. “"We're Nostalgic but We're not Crazy»: Retrofitting the Past in Russia”. The Russian Review, nr 66, 2007, ss. 451-482.

Repin, Taras. „Kak festival' molodëzhi 1957 goda izmenil SSSR”. Russkaya semerka, 18.10 2017 [Репин, Тарас. „Как фестиваль молодёжи 1957 года изменил СССР”. Русская семерка, 18.10.2017], russian7.ru/post/kak-festival-molodyozhi-1957-goda-izmenil/. Dostęp 16.12.2020.

Sekretov, Stanislav. „Istoriya bolezni”. Znamya nr 12, 2019 [Секретов, Станислав. „История болезни”. Знамя $\mathrm{nr}$ 12, 2019], znamlit.ru/publication.php?id=7465. Dostęp 3.10.2020.

Semenova, Natal'ya, i El'zhbeta Tyshkovska-Kaspshak. „Iskusstvo imitatsii i spleteniy: nostal'giya po Chekhovu v sovremennom teatre". Mezhdunarodnyy zhurnalissledovaniy kul'tury. Nostal'giya: vospominaniye - potrebleniye - rekonstruktsiya, $\mathrm{nr} 3$ (36), 2019, ss. 622 [Семенова, Наталья, и Эльжбета Тышковска-Каспшак. „Искусство имитации и сплетений: ностальгия по Чехову в современном театре”. Международный журнал исследований культуры. Ностальгия: воспоминание - потребление - реконструкция, nr 3 (36), 2019, сc. 6-22].

Smith, Laurajane, and Gary Campbell. "«Nostalgia for the Future»: Memory, Nostalgia and the Politics of Class". International Journal of Heritage Studies, t. 23, nr 7, 2017, ss. 612-627.

Sontag, Susan. Choroba jako metafora. AIDS i jego metafory. Tłum. Jarosław Anders. Państwowy Instytut Wydawniczy, 1999.

Sontag, Susan. O fotografii. Tłum. Sławomir Magala. Wydawnictwo Karakter, 2009.

Starobinski, Jean. Atrament melancholii. Tłum. Krystyna Belaid, Słowo/obraz terytoria, 2017.

Sukhanov, Vyacheslav Alekseyevich. „Nostal'giya i identichnost' - lenta Mëbiusa?”. Nostal'giya po sovetskomu, red. Zoya Ivanovna Rezanova, Izdatel'stvo Tomskogo universiteta, 2011, ss.17-22 [Суханов, Вячеслав Алексеевич. „Ностальгия и идентичность - лента Мёбиуса?". Ностальгия по советскому, ред. Зоя Ивановна Резанова, Издательство Томского университета, 2011, сc.17-22].

Toymentsev, Sergey. "Legal but Criminal: The Failure of the «Russian Nuremberg» and the Paradoxes of Post-Soviet Memory". Comparative Literature Studies, t. 48, nr 3, 2011, ss. 296-319.

\section{„NOSTALGIA TO TĘSKNOTA ZA RAJEM”. \\ PROBLEM NOSTALGII W POWIEŚCI ZBIERACZ RAJU JEWGIENIJA CZYŻOWA}

\section{Streszczenie}

Artykuł traktuje o problemie nostalgii w powieści Jewgienija Czyżowa Zbieracz raju (2019). W części wstępnej przedstawiono krótki przegląd badań nad nostalgią, wyróżniając różne jej aspekty i typologie. 
W analizie utworu główny nacisk położono na portrety centralnych postaci, których najważniejszym rysem jest stosunek do czasu, przeszłości, pamięci: Kiriłła - stałego bywalca moskiewskich pchlich targów i jego chorą na Alzheimera matkę. Oboje ilustrują różne aspekty powracania do przeszłości i brak przywiązania do teraźniejszości. W sposobach odczuwania przez nich czasu można odnaleźć różne typy nostalgii. Akcja powieści rozgrywa się w latach 90., kiedy w wyniku rozpadu Związku Radzieckiego cała przyszłość bohaterów pozostała w przeszłości. Miniona epoka nie jest jednak idealizowana, dlatego nie można określić utworu jako nostalgicznego.

Nostalgia interesuje pisarza jako zjawisko niezwykle rozpowszechnione, noszące znamiona choroby uniemożliwiającej normalne funkcjonowanie w teraźniejszości. Tęsknotę bohaterów za innymi czasami można rozpatrywać także jako frustrację wynikającą z zamknięcia człowieka w ograniczonym czasie, co uniemożliwia przeżycie wieczności.

Słowa kluczowe: nostalgia; pamięć; postpamięć; czas; lata 90.

\section{"NOSTALGIA IS A LONGING FOR PARADISE": THE ISSUE OF NOSTALGIA IN COLLECTOR OF PARADISE BY EVGENY CHIZHOV}

Su m mary

This article deals with the subject of nostalgia in the novel The Collector of Paradise (2019) by Evgeny Chizhov. The introduction presents a brief overview of research on nostalgia, while highlighting its various aspects and typologies.

In the analysis of the text, the main emphasis is placed on the portraits of the main characters: Kirill, a regular at the Moscow flea markets, and his mother, who suffers from Alzheimer's. The most distinctive feature of these characters is their relationship to time, the past and memory. They both illustrate different aspects of returning to the past and detachment from the present. Their sense of time can be said to represent different types of nostalgia. The plot of the novel takes place in the 1990s, when, as a result of the collapse of the Soviet Union, the entire future of the characters remained in the past. However, the bygone epoch is not idealised, therefore the novel cannot be labelled as nostalgic.

Nostalgia interests the writer as a widespread phenomenon with the hallmarks of a disease that prevents living in the present. The heroes' longing for a different epoch can also be viewed as frustration resulting from the confinement of a human being in a limited time, which makes it impossible to live for eternity.

Keywords: nostalgia; memory; post-memory; time; 1990s. 